\title{
Effects of Cooking Methods on the Changes of Total Anthocyanins, Phenolics Content and Physical Characteristics of Purple-Fleshed Sweet Potato (Ipomoea batatas L.) Grown in Vietnam
}

\author{
Khanh Thi Lan Phan ${ }^{\# *}$, Sasivimon Chittrakorn ${ }^{\#}$, Huan Phan Tai ${ }^{*}$, Khanitta Ruttarattanamongkol ${ }^{\#}$ \\ ${ }^{\#}$ Faculty of Agriculture, Natural Resources and Environment, Naresuan University, Phitsanulok, Thailand 65000 \\ E-mail:lankhanh@hcmuaf.edu.vn; sasivimonc@nu.ac.th;khanittar@nu.ac.th \\ *Faculty of Food Science and Technology, Nong Lam University, Ho Chi Minh City, Vietnam \\ E-mail: pthuan@hcmuaf.edu.vn
}

\begin{abstract}
Total anthocyanin content (TAC) and total phenolics in "Nhật tím" purple-fleshed sweet potato (PFSP) variety were analyzed as affected by four cooking methods: steaming, baking, roasting, and frying. Moisture content (\%), core flesh temperature $\left({ }^{\circ} \mathrm{C}\right)$ and color characteristics of cooked PFSP were evaluated. TAC in steamed, fried (skin-on), roasted, baked, and fried (skin-off) PFSP were $234.18 ; 217.14 ; 208.11 ; 195.25 ; 173.68 \mathrm{mg} / 100 \mathrm{~g}$ dry weight $(\mathrm{DW})$, respectively. Under the same cooking time, steaming was good for the retention of total phenolics and anthocyanins as compared with baking. Cooking by steaming, roasting, baking, skin-on or skin-off frying produced significant increase $(P \leq 0.05)$ of TAC and total phenolics as compared to the respective fresh samples. Steaming resulted in the greatest increase of TAC whereas skin-on frying showed a good cooking method to retain high total phenolics (826.47 mg GAE/100g DW) in shred PFSP.
\end{abstract}

Keywords - anthocyanins; total phenolics; purple-fleshed sweet potato; peel; cooking methods

\section{INTRODUCTION}

Sweet potato (Ipomoea batatas L.) is the seventh most important crop in terms of global production. In Asia, the main sweet potato producers are China, Indonesia, Vietnam, India, Philippines, and Japan [1]. The tuber crops including potato and sweet potato are the third major staple foods after cereal and legume, together with accounting for approximately $90 \%$ of the world's food calories intake [2]. In developing countries, sweet potato ranks third in value of production and fifth in caloric contribution to the human diet [3]. Purple-fleshed sweet potato (PFSP) cultivars are widely grown in Vietnam. Vinh Long province is the largest cultivation PFSP area.

PFSP anthocyanins possess a wide range of pharmacological activities such as antioxidant [4], antiinflammatory and anticarcinogenic [5], chemopreventive [6] and antihyperglycemic [7]. Willcox and Willcox [8] demonstrated that sweet potatoes are important staples of the traditional Okinawa (the southernmost prefecture of Japan) diet and are associated with longevity and low incidence of chronic degenerative diseases. However, phenolics are not distributed equally through the plant. The center of the root appeared to have lower concentrations than the surrounding cortex or the peel [9], [10]. Van Hal [11] found that phenolic compounds in sweet potato were mainly present at the outer $5 \mathrm{~mm}$ of tissue of the root. Meanwhile, regarding peeling, industrial operations reduced by $2 \%$ and $14 \%$ the root fresh mass with steam and lye-peeling methods, respectively.

Unlike fruits which are typically easily consumed in nature, without further heat treatment, most vegetables are commonly consumed after being submitted to a cooking process. Sweet potatoes are always cooked by baking, frying or boiling before consumption [12]. Cooking techniques are used to improve vegetables' palatability by softening the tissues, inactivating anti-nutritional compounds, toxic substances, and microorganisms, and forming color and flavour compounds [13]. Considering the effect of cooking, Kim et al. [14] revealed that after steaming, TAC was reduced by nearly a half, while baking only slightly reduced TAC in Korean PFSP, Shinzami whereas Tang et al. [15] reported that all cooked sweet potato exhibited significantly $(\mathrm{P} \leq 0.05)$ lower total phenolic content (TPC), monomeric anthocyanin content as compared to the respective raw samples. Murador et al. [16] asserted that in the metaanalytic approach to anthocyanin levels while cooking vegetables, moist heat techniques such as boiling and steaming reduce the anthocyanin concentrations whereas dry 
heat cooking such as microwaving and baking increase their levels.

In this present study, we reported the effects of four cooking methods on the total phenolics and the total content of anthocyanins in "Nhật tím" PFSP variety. It is common culinary practice to slice, shred or dice vegetables before cooking. This may decrease phenolic compounds content by exposing them to high moist heat. Thus, the main objective of this work was to evaluate the alteration of PFSP pigment, anthocyanins, and total phenolics after applying different cooking methods such as steaming, baking, roasting, and frying. The evaluation on different skin-on (unpeeled) and skin-off (peeled) shred PFSP in frying condition has an important significance for guiding people to a tasty and healthy diet, and it may provide evidence for the selection of a suitable cooking method of purple sweet potatoes to retain the bioactive compounds in PFSP root.

\section{MATERIALS AND METHODS}

\section{A. Raw Material}

A commercially available "Nhật tím" PFSP (140 days mature crop) was obtained from a local farm in Binh Tan District, Vinh Long Province, Vietnam. PFSP roots were selected with a range of weight $147.91 \mathrm{~g} \pm 2.2$ and diameter $42.27 \mathrm{~mm} \pm 1.9$.

\section{B. Cooking Procedures}

For frying, PFSP roots were washed, peeled (skin-off) or unpeeled (skin-on), and one PFSP root was manually cut into 4-6 pieces along the root. Shred PFSP was put into a heating basket and fried at $170^{\circ} \mathrm{C}$ for $5 \mathrm{~min}$ in $1 \mathrm{~L}$ of cooking palm oil by using an electrical deep fat fryer (Phillips, HD 6157). Then the shred PFSP were drained over a wire screen and tissue paper for $5 \mathrm{~min}$ and cooled to room temperature.

For steaming, a domestic steamer (Phillips, HD 9104) was pre-heated at $100^{\circ} \mathrm{C}$ with $1 \mathrm{~L}$ tap water at its base. PFSP roots (3 roots) were placed in the steamer covered with a lid and steamed over boiling water for $20 \mathrm{~min}$ under atmospheric pressure.

For baking, PFSP roots ( 3 roots) were baked at $200^{\circ} \mathrm{C}$ for $20 \mathrm{~min}$ in a commercial oven (Turbo Quartz, Roller Grill) after the oven had come to the prescribed temperature.

For roasting, PFSP roots (3 roots) were roasted at $250^{\circ} \mathrm{C}$ for $50 \mathrm{~min}$ in an electric oven (ST42L Osaka) after the oven had come to reach prescribed temperature.

\section{Degree of Cooking Determination}

The degree of cooking at the center (core) of cooked PFSP samples in each cooking method was expressed as center point temperature or core flesh temperature $\left({ }^{\circ} \mathrm{C}\right)$.

\section{Moisture Content (\%)}

Moisture content (\%) of the fresh PFSP and cooked PFSP was determined using the oven method following AOAC [17].

\section{E. Color Analysis}

The color determination was carried out on the surface of fresh PFSP and cooked PFSP samples using a Minolta Colorimeter (CR-400, Minolta). L* representing lightness $\left(\mathrm{L}^{*}=0\right.$ yields black and $\mathrm{L}^{*}=100$ denotes white), $\mathrm{a}^{*}(+$ redness) or (- greenness) and $\mathrm{b}^{*}$ (+ yellowness) or (blueness) were quantified on each sample. The CIELAB parameters $\left(\Delta \mathrm{L}^{*}, \Delta \mathrm{a}^{*}, \Delta \mathrm{b}^{*}\right.$, and $\left.\Delta \mathrm{E}^{*}\right)$ were determined as follows:

$$
\begin{gathered}
\Delta \mathrm{L}^{*}=\mathrm{L}^{*}{ }_{\mathrm{c}}-\mathrm{L}^{*}{ }_{\mathrm{t}} \\
\Delta \mathrm{a}^{*}=\mathrm{a}^{*}{ }_{\mathrm{c}}-\mathrm{a}^{*}{ }_{\mathrm{t}} \\
\Delta \mathrm{b}^{*}=\mathrm{b}^{*}{ }_{\mathrm{c}}-\mathrm{b}^{*}{ }_{\mathrm{t}} \\
\Delta \mathrm{E}^{*}=\sqrt{\left(\mathrm{L}_{\mathrm{c}}^{*}-\mathrm{L}_{\mathrm{t}}^{*}\right)^{2}+\left(\mathrm{a}_{\mathrm{c}}^{*}-\mathrm{a}_{\mathrm{t}}^{*}\right)^{2}+\left(\mathrm{b}_{\mathrm{c}}^{*}-\mathrm{b}_{\mathrm{t}}^{*}\right)^{2}}
\end{gathered}
$$

Where $\mathrm{L}_{\mathrm{c}}^{*}, \mathrm{a}_{\mathrm{c}}$, and $\mathrm{b}_{\mathrm{c}}$ were the color values of fresh PFSP samples, and $\mathrm{L}_{\mathrm{t}}, \mathrm{a}_{\mathrm{t}}$, and $\mathrm{b}_{\mathrm{t}}$ were the color values of cooked PFSP samples.

\section{F. Extraction and Analysis of The Total Anthocyanin Content}

To determine the total anthocyanins, the methanol extract was used followed the method of Bridgers et al. [18]. For each sample, $3.3 \%(\mathrm{w} / \mathrm{v})$ of PFSP sample was placed into a $50-\mathrm{mL}$ centrifuge tube, and approximately $25 \mathrm{~mL}$ of the extraction solvent $70 \%$ methanol with $7 \%$ acetic acid was added to the centrifuge tube. The tubes were capped and incubated for $1 \mathrm{~h}$ in a water bath at $80^{\circ} \mathrm{C}$. The tubes were centrifuged at $2750 \mathrm{x} \mathrm{g}$ for $15 \mathrm{~min}$. The supernatant was decanted, and volumes were adjusted to $25 \mathrm{~mL}$ with the extraction solvent. The resultant extract was analyzed for TAC.

The total monomeric anthocyanin content in PFSP extract was determined by the pH-differential method [19]. Two dilutions were performed on each sample. The first used potassium chloride $(0.025 \mathrm{M})$ at $\mathrm{pH} 1.0$ and the second was with sodium acetate $(0.4 \mathrm{M})$ at $\mathrm{pH}$ 4.5. The difference in absorbance between $\mathrm{pH}$ values and wavelengths was calculated as:

$$
\frac{A \times M W \times D F \times 10^{3}}{\varepsilon \times 1}
$$

Where $\mathbf{A}=\left(\mathrm{A}_{520 \mathrm{~nm}}-\mathrm{A}_{700 \mathrm{~nm}}\right) \mathrm{pH} 1.0-\left(\mathrm{A}_{520 \mathrm{~nm}}-\mathrm{A}_{700 \mathrm{~nm}}\right)$ $\mathrm{pH} 4.5$; MW (molecular weight $)=449.2 \mathrm{~g} / \mathrm{mol}$ for cyanidin3-glucoside (cyd-3-glu); DF = dilution factor (1:10); $\mathbf{l}=$ path length in $\mathrm{cm} ; \boldsymbol{\varepsilon}=26900 \mathrm{M}$ extinction coefficient, in $\mathrm{Lmol}^{-}$ ${ }^{1} \mathrm{~cm}^{-1}$, for cyd-3-glu; and $\mathbf{1 0}^{\mathbf{3}}=$ factor for conversion from $\mathrm{g}$ to $\mathrm{mg}$. The total monomeric anthocyanins were reported as milligram anthocyanins per $100 \mathrm{~g}$ dry weight (DW).

\section{G. Determination Total Phenolics}

The total phenolic content (TPC) was measured based on the method of Singleton et al. [20]. Briefly, $0.1 \mathrm{~mL}$ of sample extract was mixed with $0.5 \mathrm{~mL}$ of $10 \%$ FolinCiocalteu reagent. After $3 \mathrm{~min}, 1 \mathrm{~mL}$ of $15 \% \mathrm{Na}_{2} \mathrm{CO}_{3}$ solution was added, and the mixture was adjusted to $5 \mathrm{~mL}$ by distilled water, allowed to keep at room temperature in the darkness for $60 \mathrm{~min}$. The absorbance was recorded at 765 nm. A standard curve was made by using gallic acid, and total phenols were expressed as milligram gallic acid equivalents (GAE)/100g DW. 


\section{H. Statistical Analysis}

Data were performed using the SPSS (version 22.0) package for Windows. One-way analysis of variance (ANOVA) and Duncan's multiple range tests were carried out to determine the significance $(\mathrm{P} \leq 0.05)$ between the means. Data are reported as the mean \pm standard deviation (SD). All determinations were carried out in triplicates

\section{RESULTS AND DISCUSSION}

\section{A. Cooking Conditions and Core Flesh Temperature of Four Cooking Methods}

The cooking time and temperature for each treatment are presented in Table 1. It can be observed that frying methods with peeled (skin-off) or unpeeled (skin-on) shred PFSP were faster $(5 \mathrm{~min})$ than the steaming and baking, roasting was the longest method. However, the temperature reached by steaming process was the lowest $\left(100^{\circ} \mathrm{C}\right)$ among these cooking processes.

TABLE I

COOKING CONDITIONS

\begin{tabular}{|l|c|c|}
\hline Cooking methods & Time (min) & Temperature $\left({ }^{\mathbf{0}} \mathbf{C}\right)$ \\
\hline Steaming & 20 & 100 \\
\hline Baking & 20 & 200 \\
\hline Roasting & 50 & 250 \\
\hline Frying (skin-on) & 5 & 170 \\
\hline Frying (skin-off) & 5 & 170 \\
\hline
\end{tabular}

The temperature at the center (core) of PFSP treated by different cooking methods was also measured (Figure 1) after the cooking duration (Table 2). There were significant differences $(\mathrm{P} \leq 0.05)$ among treatments with the obtained values of temperature at the core flesh of processed PFSP in the following order: roasting, steaming, frying (skin-on), baking, and frying (skin-off). The variations can be explained by the different conditions such as temperature, heating medium (hot water vapor, hot air or hot oil) applied by these treatments which allowed for the difference in heat penetration to the core of PFSP samples and also resulted in disparities of cooking period [21]. Moreover, deep fat frying was a simultaneous heat and mass transfer process that caused microstructural and physicochemical changes inside the food during the process [22].

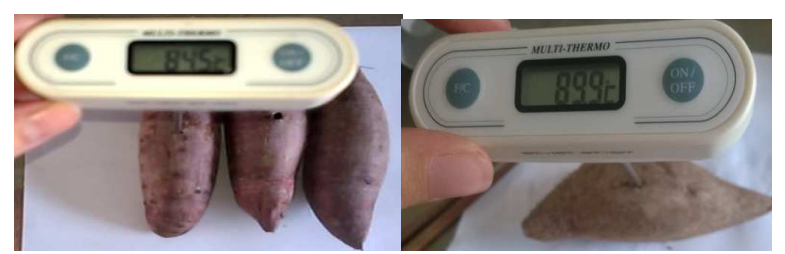

Fig. 1 Measuring temperature at the center flesh of PFSP root after cooking methods

\section{B. Moisture Content (\%)}

The moisture content of PFSP after passing different cooking methods was presented in Table 3. Baking and steaming treatments significantly $(\mathrm{P} \leq 0.05)$ retained more moisture content of PFSP samples than the other cooking procedures. This might be related to the peel and the superficial layer of cells dehydrated during baking treatment, acting as an effective barrier to the exit of water from the internal part of the PFSP and resulting in a less decrease of the moisture content in sweet potato samples [21], [23]. Along with driving off the surplus moisture inside, the main principle of baking was to get the inside of the product properly cooked before the outside dried out and became tough. In addition, though steaming cooked PFSP over a long-time period, good points of it included uniform heat distribution and an enhanced water-retaining capacity after cooking [24].

TABLE II

CoRe TeMPeRATURe $\left({ }^{\circ} \mathrm{C}\right)$ OF PFSP SAMPLES IN DifFERENT COOKING METHODS

\begin{tabular}{|l|c|c|c|}
\hline $\begin{array}{c}\text { Cooking } \\
\text { methods }\end{array}$ & Temp. $\left({ }^{\mathbf{0}} \mathbf{C}\right)$ & $\begin{array}{c}\text { Time } \\
(\mathbf{m i n})\end{array}$ & $\begin{array}{c}\text { Center point } \\
\text { temperature }\left({ }^{\mathbf{0}} \mathbf{C}\right)\end{array}$ \\
\hline Fresh PFSP & - & - & $28.27 \pm 1.8 \mathrm{~d}$ \\
\hline Baking & 200 & 20 & $90.13 \pm 0.3 \mathrm{bc}$ \\
\hline Roasting & 250 & 50 & $92.27 \pm 0.6 \mathrm{a}$ \\
\hline Frying (skin-on) & 170 & 5 & $90.50 \pm 0.7 \mathrm{~b}$ \\
\hline Frying (skin-off) & 170 & 5 & $88.77 \pm 0.4 \mathrm{c}$ \\
\hline Steaming & 100 & 20 & $91.37 \pm 0.3 \mathrm{ab}$ \\
\hline
\end{tabular}

Data in the same column followed by the same letter are not significantly $(P>0.05)$ different. The values expressed as means \pm standard deviation of triplicate experiments (on dry basis).

TABLE III

MOISTURE CONTENT (\%) OF PFSP SAMPLES IN DIFFERENT COOKING METHODS

\begin{tabular}{|l|c|c|c|}
\hline \multicolumn{1}{|c|}{$\begin{array}{c}\text { Cooking } \\
\text { methods }\end{array}$} & $\begin{array}{c}\text { Temp. } \\
\left({ }^{\mathbf{O}} \mathbf{C}\right)\end{array}$ & $\begin{array}{c}\text { Time } \\
(\mathbf{m i n})\end{array}$ & $\begin{array}{c}\text { Moisture content } \\
(\boldsymbol{\%})\end{array}$ \\
\hline Fresh PFSP & - & - & $68.44 \pm 0.4 \mathrm{~b}$ \\
\hline Baking (skin- & 170 & 5 & $64.11 \pm 0.4 \mathrm{c}$ \\
\hline Roasting & 200 & 20 & $59.96 \pm 0.4 \mathrm{~d}$ \\
\hline $\begin{array}{l}\text { Frying (skin- } \\
\text { on) }\end{array}$ & 170 & 5 & $51.52 \pm 1.7 \mathrm{f}$ \\
\hline $\begin{array}{l}\text { Frying } \\
\text { off) }\end{array}$ & 100 & 20 & $71.72 \pm 0.2 \mathrm{a}$ \\
\hline Steaming
\end{tabular}

Data in the same column followed by the same letter are not significantly $(P>0.05)$ different. The values expressed as means \pm standard deviation of triplicate experiments (on dry basis).

\section{Color Parameters}

The color was an important sensory property; therefore any color change would make an impact on the acceptance of processed sweet potatoes by consumers [25]. The color measurement of thermal treated PFSP was expressed as $\Delta \mathrm{L}^{*}$ difference in lightness and darkness $(+=$ lighter, $-=$ darker $)$, $\Delta \mathrm{a}^{*}$ difference in red and green $(+=$ redder, $-=$ greener $)$, $\Delta \mathrm{b}^{*}$ difference in yellow and blue $(+=$ yellower, $-=$ bluer $)$ and $\Delta \mathrm{E}^{*}$ total difference color values and presented in Table 4.

Steaming, which had lower $\Delta \mathrm{L}^{*}$ and $\Delta \mathrm{b}^{*}$ values, and higher $\Delta \mathrm{a}^{*}$ values than other roasting and baking, resulting in intensive purple chroma with high anthocyanin contents. These current results were in agreement with the fact that cyanidin- and peonidin- based anthocyanins are the major anthocyanins found in PFSP root contribute to the blue and red hues of the root [26], [27]. Huang et al. [25] reported that 
thermal treatment resulted in gelatinization of starch granules and a significant color change. The total color differences $\left(\Delta \mathrm{E}^{*}\right)$ before and after frying (skin-off) were much higher than those obtained by roasting, steaming, frying (skin-on) and baking. In this current study, the total color difference $\left(\Delta \mathrm{E}^{*}\right)$ value in the baking treatment of "Nhật tím" PFSP variety was 10.9 and drastically lower than those observed in the previous study of Kim et al. [28]. The results showed that total color differences $\left(\Delta \mathrm{E}^{*}\right)$ before and after baking of two Korean purple-fleshed cultivars were 21.2 and 16.1 in Sinjami and Yeonjami, respectively. Sinjami cultivar had higher anthocyanin contents than Yenjami cultivar. The overall decrease in $\mathrm{L}^{*}, \mathrm{a}^{*}$, and $\mathrm{b}^{*}$ values after all cooking treatments could be related to anthocyanin loss because of the natural pigments are less stable to light, heat, and oxygen. It has been reported that food processing and storage reduced anthocyanin contents in food materials and changed their chemical conformation [29].

TABLE IV

COLOR CHARACTERISTICS OF PROCESSED PFSP SAMPLES

\begin{tabular}{|c|c|c|c|c|}
\hline \multirow{2}{*}{$\begin{array}{l}\text { Cooking } \\
\text { methods }\end{array}$} & \multicolumn{4}{|c|}{ Color value } \\
\hline & $\Delta \mathbf{L}^{*}$ & $\Delta a^{*}$ & $\Delta \mathbf{b}^{*}$ & $\Delta \mathbf{E}^{*}$ \\
\hline Baking & $\begin{array}{l}-6.0 \pm \\
1.2 \mathrm{ab}\end{array}$ & $\begin{array}{l}-8.1 \pm \\
2.0 \mathrm{~b}\end{array}$ & $\begin{array}{c}-4.0 \pm \\
0.8 b\end{array}$ & $10.9 \pm 1.9 \mathrm{c}$ \\
\hline Roasting & $\begin{array}{c}-3.7 \pm \\
3.8 \mathrm{a}\end{array}$ & $\begin{array}{c}-16.0 \pm \\
1.4 \mathrm{c}\end{array}$ & $0.8 \pm 0.8 \mathrm{a}$ & $16.7 \pm 2.4 b$ \\
\hline $\begin{array}{c}\text { Frying } \\
\text { (skin-on) }\end{array}$ & $\begin{array}{l}-9.5 \pm \\
3.9 \mathrm{~b}\end{array}$ & $\begin{array}{l}-7.1 \pm \\
1.8 \mathrm{~b}\end{array}$ & $1.3 \pm 0.6 \mathrm{a}$ & $12.1 \pm 3.3 \mathrm{c}$ \\
\hline $\begin{array}{c}\text { Frying } \\
\text { (skin-off) }\end{array}$ & $\begin{array}{c}-14.5 \pm \\
1.8 \mathrm{c}\end{array}$ & $\begin{array}{c}-14.5 \pm \\
1.4 \mathrm{c}\end{array}$ & $1.6 \pm 0.9 \mathrm{a}$ & $20.7 \pm 1.7 \mathrm{a}$ \\
\hline Steaming & $\begin{array}{c}-14.4 \pm \\
0.7 \mathrm{c}\end{array}$ & $\begin{array}{c}-3.3 \pm \\
1.5 \mathrm{a}\end{array}$ & $\begin{array}{c}-7.2 \pm \\
0.7 \mathrm{c}\end{array}$ & $16.5 \pm 0.6 b$ \\
\hline
\end{tabular}

Data in the same column followed by the same letter are not significantly $(P>0.05)$ different. The values expressed as means \pm standard deviation of triplicate experiments (on dry basis).

\section{Anthocyanin Content}

The influence of different cooking methods on TAC of PFSP samples was evaluated on a dry matter basis in Table 5. The current result showed that the content of TAC of cooked PFSP increased significantly $(\mathrm{P} \leq 0.05)$ across all of the treatments with a range of 173.68 to $234.18 \mathrm{mg} / 100 \mathrm{~g}$ DW as compared with the fresh PFSP (111.56 mg/100g DW). Steaming resulted in the greatest increase $(243.18$ $\mathrm{mg} / 100 \mathrm{~g} \mathrm{DW}$, followed by skin-on frying (217.1418 $\mathrm{mg} / 100 \mathrm{~g}$ DW), roasting $(208.11 \mathrm{mg} / 100 \mathrm{~g}$ DW), baking $(195.25 \mathrm{mg} / 100 \mathrm{~g} \mathrm{DW})$ and skin-off frying $(173.68 \mathrm{mg} / 100 \mathrm{~g}$ DW). In common with other polyphenols, anthocyanins are enzymatically degraded in the presence of polyphenol oxidase (PPO), peroxidase (POD) and glycosidase in plant tissue. These enzymes can be inactivated by mild heating and can have a positive effect on anthocyanin retention. Therefore, cooking process inactivated these indigenous enzymes in fresh PFSP, retaining anthocyanins in cooked samples [30].

In addition, heat treatment could soften the vegetable tissue, facilitating the extraction of this compound from the cellular matrix [31] and result in an increase of anthocyanin levels. Under the same cooking time, steaming method was good for keeping anthocyanins as compared with baking method. Cipriano et al. [32] also reported that heat could increase tissue softening and initiated starch gelatinization and it was also justified by the increase in anthocyanin content. Moreover, Lu et al. [33] supported that the anthocyanins from purple sweet potatoes were more stable than those from strawberry, red cabbage, and other plants. During processing and storage, acylated anthocyanins were more stable than their nonacylated analogs [34].

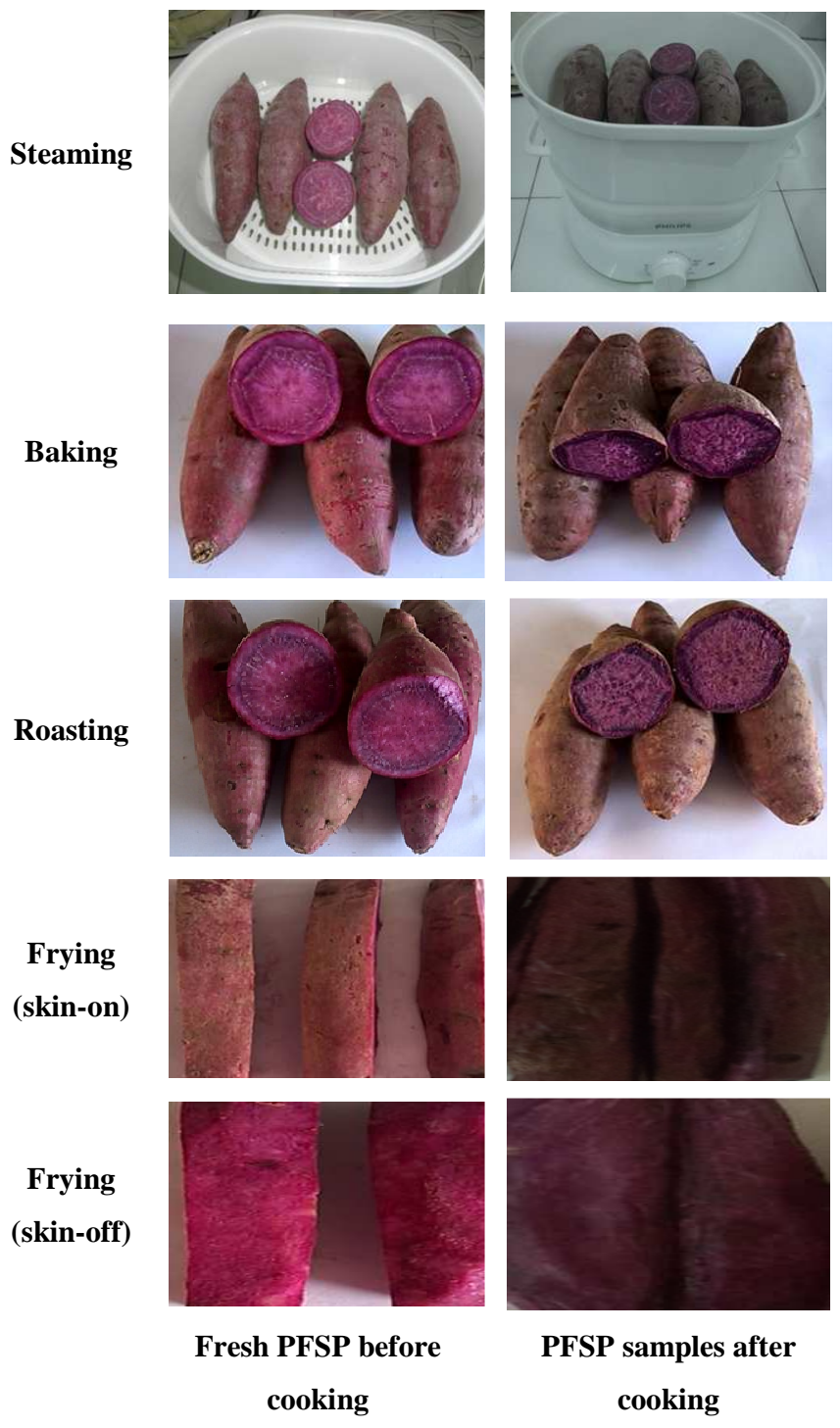

Fig. 2 PFSP before and after different cooking treatments

Anthocyanins in PFSP primarily occurred as acylated compounds [35], [36]. The acylated anthocyanins from PFSP have been reported to show a relatively stable to heat and light [37], [38]. However, thermal degradation of anthocyanins could result in a variety of PFSP species depending upon the severity and nature of heating. Kim et al. [14] demonstrated that the total content of anthocyanin in PFSP (Shinzami) decreased by nearly half upon steamcooking at $121^{\circ} \mathrm{C}$ for $10 \mathrm{~min}$ but only slight upon baking for $40-50 \mathrm{~min}$ at $200^{\circ} \mathrm{C}$. According to Hong and Koh [39], TAC in cooked purple sweet potatoes decreased by $51-81 \%$ as compared of the raw purple sweet potatoes. Tang et al. 
[15] also revealed that all cooked sweet potato exhibited significantly $(\mathrm{P} \leq 0.05)$ lower monomeric anthocyanin content as compared to the respective raw samples. The loss of total anthocyanins occurred during all of the homeprocessing methods. Baked, boiled and steamed sweet potatoes $(5.31 \pm 0.06,4.17 \pm 0.01$ and $3.36 \pm 0.06 \mathrm{mg} / \mathrm{g} \mathrm{DW}$, respectively) showed higher amounts of anthocyanins than pressure-cooked, sautéed and fried sweet potatoes [28].

TABLE V

TOTAL ANTHOCYANIN CONTENT (MG/100G DW) OF COOKED PFSP BY FOUR COOKING METHODS

\begin{tabular}{|l|c|c|l|}
\hline $\begin{array}{l}\text { Cooking } \\
\text { methods }\end{array}$ & Temp. ${ }^{\mathbf{o} C)}$ & $\begin{array}{l}\text { Time } \\
(\mathbf{m i n})\end{array}$ & $\begin{array}{l}\text { Total } \\
\text { anthocyanins } \\
(\mathbf{m g} / \mathbf{1 0 0 g} \text { DW })\end{array}$ \\
\hline Fresh PFSP & - & - & $111.56 \pm 2.8 \mathrm{f}$ \\
\hline Baking & 200 & 20 & $195.25 \pm 4.2 \mathrm{~d}$ \\
\hline Roasting & 250 & 50 & $208.11 \pm 3.2 \mathrm{c}$ \\
\hline Frying (skin-on) & 170 & 5 & $217.14 \pm 4.4 \mathrm{~b}$ \\
\hline Frying (skin-off) & 170 & 5 & $173.68 \pm 1.5 \mathrm{e}$ \\
\hline Steaming & 100 & 20 & $234.18 \pm 5.1 \mathrm{a}$ \\
\hline
\end{tabular}

Data in the same column followed by the same letter are not significantly $(P>0.05)$ different. The values expressed as means \pm standard deviation of triplicate experiments (on dry basis).

\section{E. Total Phenolics}

Phenolic compounds can reduce reactive oxygen species (ROS) levels which can cause chronic diseases, especially cancer and arteriosclerosis, by trapping and dissipating free radicals [40]. Four different cooking methods were applied to determine the variation in total phenolics during the cooking processes. The content of total phenolics in the PFSP before and after cooking treatment is presented in Table 6. There were significant $(\mathrm{P} \leq 0.05)$ differences between the treatments, with increase occurring in the following order: frying (skin-on), steaming, roasting and frying (skin-off). TPC increased significantly $(\mathrm{P} \leq 0.05)$ after all the cooking methods examined, particularly after frying (skin-on) (826.47mg GAE/100g DW) and steaming (779.64mg GAE/100g DW). The largest increase was observed in the skin-on frying process. The reason could be explained by the results of Zhu et al. [41] showed that sweet potato peels possessed high levels of phenolics and the TPC found in raw sweet potato skin $(17.7 \mathrm{mg}$ chlorogenic acid equivalents $(\mathrm{CAE}) / \mathrm{g}$ ) tissue was significantly higher than in raw cortex $(2.96 \mathrm{mg} \mathrm{CAE} / \mathrm{g})$ and raw pith tissue $(2.08 \mathrm{mg}$ $\mathrm{CAE} / \mathrm{g}$ ) [42]. Van Hal [11] also found that phenolic compounds in sweet potato were mainly present at the outer $5 \mathrm{~mm}$ of tissue of the root and deep fat frying was a simultaneous heat and mass transfer process that caused microstructural and physicochemical changes inside the food during the process [43].

This current study agreed with the result of Rautenbach et al. [44] observing a rise (21-79\%) in TPC in four cultivars of sweet potato after thermal processing. Truong et al. [45] and Bellail et al. [46] also demonstrated that thermal processing resulted in increasing the concentration of the total phenolic acids of sweet potato. This increase could be explained partly by the rise in extractability of phenolics of wet cooked soft tissue and the release of the phenolic compound bound to the cell walls [24], [47], [48].
TABLE VI

CONTENTS OF TOTAL PHENOLICS (MG GAE/100G DW) OF COOKEd PFSP IN FOUR COOKING METHODS

\begin{tabular}{|l|c|c|c|}
\hline $\begin{array}{c}\text { Cooking } \\
\text { methods }\end{array}$ & Temp. $\left({ }^{\mathbf{o}} \mathbf{C}\right)$ & $\begin{array}{c}\text { Time } \\
(\mathbf{m i n})\end{array}$ & $\begin{array}{c}\text { Total phenolics } \\
(\mathbf{m g} \text { GAE/100g } \\
\text { DW })\end{array}$ \\
\hline Fresh PFSP & - & - & $507.73 \pm 4.8 \mathrm{f}$ \\
\hline Baking & 200 & 20 & $694.09 \pm 4.1 \mathrm{c}$ \\
\hline Roasting & 250 & 50 & $674.78 \pm 3.8 \mathrm{~d}$ \\
\hline Frying (skin-on) & 170 & 5 & $826.47 \pm 4.4 \mathrm{a}$ \\
\hline Frying (skin-off) & 170 & 5 & $660.18 \pm 2.5 \mathrm{e}$ \\
\hline Steaming & 100 & 20 & $779.64 \pm 5.3 \mathrm{~b}$ \\
\hline
\end{tabular}

Data in the same column followed by the same letter are not significantly $(P>0.05)$ different. The values expressed as means \pm standard deviation of triplicate experiments (on dry basis).

\section{CONCLUSIONS}

Interestingly, the present results showed that total phenolics and TAC of those steamed-, baked-, roasted- , fried (skin-on)- and fried (skin-off)- PFSP samples in four domestic cookings (i.e., steaming, baking, roasting and frying method) were significant $(\mathrm{P} \leq 0.05)$ higher than the fresh PFSP samples. The greatest was observed in the steaming method. Considering the results obtained for the "Nhật tím" PFSP variety, from a nutritional standpoint, steaming rather than baking and roasting can be recommended for PFSP cooking. As a consequence, the frying with skin could be considered a recommended cooking method to retain phenolic compounds and anthocyanin pigment. Therefore, in order to enhance the bioactive compounds of PFSP root, care needs to be taken to select cooking methods. These results suggested that the consumption of whole cooked PFSP should be recommended as a good source of phenolic compounds in a diet.

\section{ACKNOWLEDGMENT}

The authors would like to thank for the Faculty of Food Science and Technology, Nong Lam University, Vietnam for kindly support of raw materials. This study was carried out with the financial support of Naresuan University, Thailand.

\section{REFERENCES}

[1] FAO (Food and Agriculture Organization of the United Nations) (2012). Available: http://www feedipedia.org/node/745

[2] Aina, A. J., Falade, K. O., Akingbala, J.O., Tirtus, P., "Physicochemical properties of Caribbean sweet potato (Ipomoea batatas (L) Lam) starches", Food Bioprocess Technol, vol. 5 (2), pp. 576-583, 2012.

[3] Mohan, C. Ed., Tropical tuber crops. In H. P. Singh \& V. A. Parthasarathy, Advances in Horticultur biotechnology: Molecular markers and marker assisted selection-vegetables, ornamentals and tuber crops. India: Westville Publishing House, New Delhi, pp. 187230, 2011.

[4] Hu, Y., Deng, L., Chen, J., Zhou, S., Liu, S., Fu, Y., et al. \& Chen, M., "An analytical pipeline to compare and characterise the anthocyanin antioxidant activities of purple sweet potato cultivars", Food Chemistry, vol.194, pp. 46-54, 2016.

[5] Sugata, M., Lin, C.Y., \& Shih, Y.C., "Anti-inflammatory and anticancer activities of Taiwanese purple-fleshed sweet potatoes (Ipomoea batatas L. Lam) extracts", BioMed Research International, http://dx.doi.org/10.1155/2015/768093 ID 768093, 2015. 
[6] Konczak-Islam, I., Yoshimoto, M., Hou, D.-X., Terahara, N., \& Yamakawa, O., "Potential chemopreventive properties of anthocyanin-rich aqueous extracts from in vitro produced tissue of sweetpotato (Ipomoea batatas L.)", Journal of Agricultural and Food Chemistry, vol. 51, pp. 5916-5922, 2003.

[7] Matsui, T., Ebuchi, S., Kobayashi, M., Fukui, K., Sugita, K., Terahara, N., \& Matsumoto, K., "Anti-hyperglycemic effect of diacylated anthocyanin derived from Ipomoea batatas cultivar Ayamurasaki can be achieved through the aglucosidase inhibitory action", Journal of Agricultural and Food Chemistry, vol. 50, pp. 7244-7248, 2002.

[8] Willcox, B. J., \& Willcox, D. C., "Caloric restriction, caloric restriction mimetics, and healthy aging in Okinawa: Controversies and clinical implications", Current Opinion in Clinical Nutrition and Metabolic Care, vol. 17, pp. 51-58, 2014.

[9] Padda, M.S., Picha, D.H., "Antioxidant activity and phenolic composition in 'Beauregard' sweetpotato are affected by root size and leaf age", Journal of the American Society for Horticultural Science, vol. 132, pp. 447-451, 2007.

[10] Walter Jr., W.M., \& Schadel, W.E., "Distribution of phenols in "Jewel", sweet potato [Ipomoea batatas (L.) Lam.] roots", Journal of Agricultural and Food Chemistry, vol. 29, pp. 904-906, 1981.

[11] Van Hal, M., "Quality of sweet potato flour during processing and storage", Food Reviews International, vol. 16, pp.1-37, 2000.

[12] Tarmizi, A. H.A., \& Niranjan, K., "Post-frying oil drainage from potato chips and French fries: a comparative study of atmospheric and vacuum drainage", Food Bioprocess Technol, vol. 6 (2), pp. 489497, 2013.

[13] Fennema, O. R. 3rd Ed., Food chemistry, Taylor \& Francis, 1996.

[14] Kim, H.W., Kim, J.B., Cho, S.M., Chung, M.N., Lee, Y.M., Chu, S.M., Che, J.H., Kim, S.N., Kim, S.Y., Cho, Y.S., Kim, J.H., Park, H.J., Lee, D.J., "Anthocyanin changes in the Korean purple-fleshed sweet potato, Shinzami, as affected by steaming and baking", Food Chemistry, vol. 130, pp. 966-972, 2012.

[15] Tang, Y., Cai, W. \& Xu, B., "Profiles of phenolics, carotenoids and antioxidative capacities of thermal processed white, yellow, orange and purple sweet potatoes grown in Guilin, China", Food Science and Human Wellness, vol. 4, pp. 123-132, 2015.

[16] Murador, D.C., da Cunha, D.T., de Rosso, V.V., "Effects of cooking techniques on vegetable pigments: A meta-analytic approach to carotenoid and anthocyanin levels", Food Research International, vol. 65 , pp.177-183, 2014.

[17] AOAC International (2007) Official methods of analysis, 18th edn, 2005; Current through revision 2, 2007 (Online). AOAC International, Gaithersburg, MD

[18] Bridgers, E. N., Chinn, M. S. \& Truong, V.D., "Extraction of anthocyanins from industrial purple-fleshed sweet potatoes and enzymatic hydrolysis of residues for fermentable sugars", Industrial Crops and Products, vol. 32, pp. 613-620, 2010.

[19] Giusti, M. \& Wrolstad, R. Ed., Characterization and measurement of anthocyanins by UV-visible spectroscopy. In: Wrolstad, R., Schwartz, S, Current Protocols in Food Analytical Chemistry. John Wiley \& Sons Inc., New York, pp. F1.2, 1-13F, 2001.

[20] Singleton, V. L., Orthofer, R., \& Lamuela-Raventós, R. M., "Analysis of total phenols and other oxidation substrates and antioxidants by means of Folin-Ciocalteu reagent", Methods in Enzymology, vol. 299, pp. 152-178, 1999.

[21] Chiavaro, E., Barbanti, D., Vittadini, E., Massini, R., "The effect of different cooking methods on the instrumental quality of potatoes (cv. Agata)", Journal of Food Engineering, vol. 77, pp. 169-178, 2006

[22] Barutcu, I., Sahin, S., \& Sumnu, G., "Effects of microwave frying and different flour types addition on the microstructure of batter coatings", Journal of Food Engineering, vol. 95(4), pp. 684-692, 2009.

[23] Ni, H., Datta, A. K., "Heat and moisture transfer in baking of potato slabs", Drying Technology, vol. 17, pp. 2069-2092, 1999.

[24] Xu, Y., Chen, Y., Cao, Y., Xia, W., Jiang, Q., "Application of simultaneous combination of microwave and steam cooking to improve nutritional quality of cooked purple sweet potatoes and saving time", Innovative Food Science and Emerging Technologies, vol. 36, pp. 303-310, 2016.

[25] Huang, C.L., Lai, Y.C., Chan, C.F., Lao, W.C., "Effect of baking treatment on starch morphology and color change of sweet potatoes", Journal of Food, Agriculture and Environment, vol. 11, pp. 400-402, 2013.
[26] Truong, V. D., Deighton, N., Thompson, R.T., McFeeters, R.F., Dean, L.O., Pecota, K.V., Yencho, G.C., "Characterization of anthocyanins and anthocyanidins in purple-fleshed sweet potatoes by HPLC-DAD/ESI-MS/MS", Journal of Agricultural and Food Chemistry, vol. 58, pp. 404-410, 2010.

[27] Lee, M.J., Park, J.S., Choi, D.S., Jung, M.Y., "Characterization and quantitation of anthocyanins in purple-fleshed sweet potatoes cultivated in Korea by HPLCDAD and HPLC-ESI-QTOF-MS/MS", Journal of Agricultural and Food Chemistry, vol. 61, pp. 3148-3158, 2013.

[28] Kim, H. J., Park, W. S., Bae, J. Y., Kang, S. Y., Yang, M. H., Lee, S., Lee, H. S., Kwak, S. S., Ahn, M. J., "Variations in the carotenoid and anthocyanin contents of Korean cultural varieties and homeprocessed sweet potatoes", Journal of Food Composition and Analysis”, vol. 41,pp. 188-193, 2015.

[29] Grace, M.H., Yousef, G.G., Gustafson, S.J., Truong, V.-D., Yencho, G.C., Lila, M.A., "Phytochemical changes in phenolics, anthocyanins, ascorbic acid, and carotenoids associated with sweet potato storage and impacts on bioactive properties", Food Chemistry, vol. 145, pp. 717-724, 2014

[30] Yang, J. \& Gadi, R. L., "Effects of steaming and dehydration on anthocyanins, antioxidant activity, total phenols and color characteristics of purple-fleshed sweet ptatoes (Ipomoea batatas)", American Journal of Food Technology, vol. 3, pp. 224-234, 2008.

[31] Blessington, T., Nzaramba, M. N., Scheuring, D. C., Hale, A. L., Reddivari, L., Miller, J. C., "Cooking methods and storage treatments of potato: Effects on carotenoids, antioxidant activity, and phenolics", American Journal of Potato Research, vol. 87(6), pp. 479-491, 2010.

[32] Cipriano, P. D. A, Ekici, L., Barnes, R. C., Gomes, C., Talcott, S. T. "Pre-heating and polyphenol oxidase inhibition impact on extraction of purple sweet potato anthocyanins", Food Chemistry, vol. 180, pp. 227-234, 2015.

[33] Lu, L.Z., Zhou, Y.Z., Zang, Y.Q., “Anthocyanin extracts from purple sweet potato by means of microwave baking and acidified electrolysed water and their antioxidation in vitro", International Journal of Food Science and Technology, vol. 45, pp. 1378-1385, 2010.

[34] Dyrby, M., Westergaard, N., \& Stapelfeldt, H., "Light and heat sensitivity of red cabbage extract in soft drink model systems", Food Chemistry, vol. 72, pp. 431-437, 2001.

[35] Goda, Y., Shimizu, T., Kato, Y., Nakamura, M., Maitani, T., Yamada, T., "Two acylated anthocyanins from purple sweet potato", Phytochemistry, vol. 44(1), pp. 183-186, 1997.

[36] Terahara, N., Shimizu, T., Kato, Y., Nakamura, M., Maitani, T. Yamaguchi, M., "Six diacylated anthocyanins from the storage roots of purple sweet potato, Ipomoea batatas", Bioscience, Biotechnology and Biochemistry, vol. 63(8), pp. 1420-1424, 1999.

[37] Hayashi, K., Ohara, N. \& Tsukui, A., "Stability of anthocyanins in various vegetables and fruits", Food Science Technology International, vol. 2, pp. 30-33, 1996.

[38] Bolívar, A.C.C., \& Luis C.Z., "Stability of anthocyanin-based aqueous extracts of Andean purple corn and red-fleshed sweet potato compared to synthetic and natural colorants", Food Chemistry, vol. 86, pp. 69-77, 2004.

[39] Hong, K. H. \& Koh, E., "Effects of cooking methods on anthocyanins and total phenolics in purple-fleshed sweet potato", Journal of Food Processing and Preservation, vol. 40, pp. 10541063, 2016

[40] Choe, E., Min, D. B.,."Chemistry and reactions of reactive oxygen species in foods", Journal of Food Science, vol. 70, pp. R142-R159, 2005.

[41] Zhu, F., Cai, Y.Z., Yang, X.S., Ke, J.X., Corke, H., “Anthocyanins, hydroxycinnamic acid derivatives, and antioxidant activity in roots of different Chinese purple fleshed sweet potato genotypes", Journal of Agricultural and Food Chemistry, vol. 58, pp. 7588-7596, 2010.

[42] Padda, M. S., \& Picha, D. H., "Phenolic composition and antioxidant capacity of different heat-processed forms of sweet potato cv. 'Beauregard",, International Journal of Food Science and Technology, vol. 43, pp. 1404-1409, 2008.

[43] Barutcu, I., Sahin, S., \& Sumnu, G., "Effects of microwave frying and different flour types addition on the microstructure of batter coatings", Journal of Food Engineering, vol. 95(4), pp. 684-692, 2009.

[44] Rautenbach, F., Faber, M., Laurie, S., Laurie, R., "Antioxidan capacity and antioxidant content in roots of 4 sweet potato varieties", Journal of Food Science, vol. 75, pp. 400-405, 2010. 
[45] Truong, V. D., Mcfeeters, R. F., Thompson, R. T., Dean, L. L., Shofran, B., "Phenolic acid content and composition in leaves and roots of common commercial sweet potato (Ipomea batatas L.) cultivars in the United States", Journal of Food Science, vol. 72, pp. 343-349, 2007.

[46] Bellail, A. A., Shaltout, O. E., Youssef, M. M., El Gamal, A. M. A., "Effect of home-cooking methods on phenolic composition and antioxidant activity of sweet potato (Ipomoea batatas (L.) Lam.) cultivars grown in Egypt", Food and Nutrition Science, vol. 3, pp. 490-499, 2012.
[47] Xu, B., \& Chang, S. K., "Total phenolic, phenolic acid, anthocyanin, Flavan-3-ol, and flavonol profiles and antioxidant properties of pinto and black beans (Phaseolus vulgaris L.) as affected by thermal processing", Journal of Agricultural and Food Chemistry, vol. 57(11), pp. 4754-4764, 2009.

[48] Zaro, M. J., Ortiz, L. C., Keunchkarian, S., Chaves, A. R., Vicente, A. R., Concellón, A., "Chlorogenic acid retention in white and purple eggplant after processing and cooking", LWT - Food Science and Technology, vol. 64, pp. 802-808, 2015. 